\title{
Aspek Sosiologis Tindak Pidana Perzinaan Atas Suami Yang Nikah Dibawah Tangan (Siri) Tanpa Izin Poligami
}

\author{
Margo Hadi Pura ${ }^{1}$, Hana Faridah ${ }^{2 *}$ \\ ${ }^{12}$ Fakultas Hukum, Universitas Singaperbangsa Karawang \\ *Korespondensi: hana.faridah@fh.unsika.ac.id
}

Info Artikel

Diterima : 31 Mei $2020 \quad$ Direvisi : 14 Jun 2020 Disetujui : 11 Jul $2020 \quad$ Diterbitkan : 7 Des 2020

DOI: https://doi.org/10.31599/krtha.v14i2.141

Keywords : criminal acts, married siri, polygamy

Abstract : Siri marriages which are religiously considered legitimate in fact raise a lot of problems that result in losses on the part of women. A marriage without permission from a legal wife can provide room for adultery, adultery is regulated in article 284 of the Criminal Code as long as the perpetrator of a unregistered marriage cannot prove that there is indeed a legal marriage as stipulated in Article 2 paragraph (1) of the Company Law, and can only be prosecuted based There is a complaint from a contaminated wife / husband (complaint offense). The purpose of this study was to determine the society's view of unregistered marriage to be legal according to religion and based on article 284 and to find out the legal protection for wives who are neglected by their husbands who are already unmarried. The research method used is the normative juridical approach or normative law research method (library law research) which is carried out by first examining literature materials that are relevant to the problem under study and referring to the legal norms contained in statutory regulations. . Problems that accompany unregistered marriage, especially for women, include family problems, social and psychological problems. Legally, unregistered marriage for women is that the wife is not considered a legal wife and is not entitled to inheritance if the husband dies, is not entitled to this price in the event of separation. This impact also applies to the biological child resulting from a siri marriage.

Kata kunci : tindak pidana, nikah siri, poligami
Abstrak : Pernikahan siri yang secara agama dianggap sah pada kenyataannya justru memunculkan banyak sekali permasalahan yang berimbas pada kerugian di pihak perempuan. Nikah siri tanpa adanya izin dari istri yang sah dapat memberi ruang delik perzinaan, perzinaan diatur dalam pasal 284 KUHP sepanjang pelaku nikah siri tidak dapat membuktikan bahwa benar telah ada perkawinan yang sah sebagaimana ketentuan Pasal 2 ayat (1) UUP, dan hanya bisa dituntut berdasarkan adanya pengaduan dari istri/suami yang tercemar (delik aduan). Tujuan penelitian ini untuk mengetahui pandangan masyarakat atas nikah siri menjadi sah menurut agama serta berdasarkan pasal 284 dan mengetahui perlindungan hukum bagi istri yang ditelantarkan oleh suaminya yang sudah nikah siri. Metode penelitian yang dipergunakan adalah metode pendekatan Yuridis Normatif atau metode penelitian Hukum Normatif (penelitian hukum kepustakaan) yang dilakukan dengan cara terlebih dahulu meneliti bahan-bahan kepustakaan yang relevan dengan permasalahan yang diteliti dan mengacu kepada norma-norma hukum yang terdapat dalam peraturan perundang-undangan. 
Permasalahan yang menyertai pernikahan siri, khususnya bagi perempuan, antara lain masalah keluarga, masalah sosial serta psikologis. Secara hukum, pernikahan siri bagi perempuan adalah bahwa istri tidak dianggap sebagai istri sah dan tidak berhak mendapat warisan jika suami meninggal, tidak berhak mendapat harga gono-gini bila terjadi perpisahan. Dampak tersebut juga belaku bagi anak kandung hasil pernikahan siri.

\section{PENDAHULUAN}

Hukum positif di Indonesia tidak mengenal adanya istilah nikah siri (perkawinan siri), terlebih lagi mengatur secara khusus mengenai perkawinan siri dalam sebuah peraturan perundang-undangan. Istilah siri sendiri berasal dari bahasa arab sirra, israr yang berarti rahasia. Nikah siri di dalam masyarakat sering diartikan dengan;

1. Pernikahan tanpa wali Pernikahan semacam ini dilakukan secara rahasia (siri) dikarenakan pihak wali perempuan tidak setuju; atau karena menganggap sah pernikahan tanpa wali atau hanya karena ingin memuaskan nafsu syahwat belaka tanpa mengindahkan lagi ketentuan-ketentuan syariat.

2. Pernikahan yang sah secara agama (memenuhi ketentuan syarat dan rukun nikah/kawin) namun tidak dicatatkan pada kantor pegawai pencatat nikah (KUA bagi yang beragama Islam, Kantor Catatan Sipil bagi yang Non-Islam).

3. Pernikahan yang dirahasiakan karena pertimbangan-pertimbangan tertentu; misalnya karena takut mendapatkan stigma negatif dari masyarakat yang terlanjur menganggap tabu pernikahan siri; atau karena pertimbangan-pertimbangan rumit yang memaksa seseorang untuk merahasiakan pernikahannya. ${ }^{1}$

Di Indonesia perkawinan diatur dalam UU No. 1 Tahun 1974 Tentang Perkawinan (UUP). Pasal 2 ayat (1) UUP menyebutkan bahwa: "Perkawinan adalah sah, apabila dilakukan menurut bukum masing-masing agamanya dan kepercayaannya itu." Jadi perkawinan adalah sah bila telah dilakukan menurut hukum agama dan kepercayaan pasangan yang kawin. Pasal ini menempatkan hukum agama dan kepercayaan adalah hal yang paling utama dalam perkawinan, dan secara implisit tidak ada larangan oleh Negara $\begin{array}{llll}\text { terhadap nikah liri. Namun, lebih } & \end{array}$ ayat (2) UUP menyebutkan adanya kewajiban untuk tiap-tiap perkawinan dicatat menurut peraturan perundang-undangan yang berlaku. Perkawinan yang dicatatkan guna mendapatkan akta perkawinan. Akta perkawinan adalah bukti telah

1 https://dalamislam.com/hukum-islam/pernikahan/nikah-siri-dalam-islam, diakses pada tanggal 28 mei 2020. 
terjadinya/berlangsungnya perkawinan, bukan yang menentukan sah tidaknya perkawinan. ${ }^{2}$ Tidak ada bukti inilah yang menyebabkan anak maupun istri dari perkawinan siri tidak memiliki status hukum (legalitas) di hadapan Negara. Namun, lebih lanjut Pasal 2 ayat (2) UUP menyebutkan adanya kewajiban untuk tiap-tiap perkawinan dicatat menurut peraturan perundang-undangan yang berlaku. Perkawinan yang dicatatkan guna mendapatkan akta perkawinan. Akta perkawinan adalah bukti telah terjadinya/berlangsungnya perkawinan, bukan yang menentukan sah tidaknya perkawinan. Tidak ada bukti inilah yang menyebabkan anak maupun istri dari perkawinan siri tidak memiliki status hukum (legalitas) di hadapan Negara.

Ketentuan tentang Perzinaan diatur di dalam Pasal 284 Kitab Undang-Undang Hukum Pidana (KUHP), yang berbunyi sebagai berikut:

1. Diancam dengan pidana penjara paling lama sembilan bulan:

a. seorang pria yang telah kawin yang melakukan gendak (overspel), padahal diketahui bahwa pasal 27 BW berlaku baginya, seorang wanita yang telah kawin yang melakukan gendak, padahal diketahui bahwa pasal 27 BW berlaku baginya;

b. seorang pria yang turut serta melakukan perbuatan itu, padahal diketahuinya bahwa yang turut bersalah telah kawin;

c. seorang wanita yang telah kawin yang turut serta melakukan perbuatan itu, padahal diketahui olehnya bahwa yang turut bersalah telah kawin dan pasal 27 BW berlaku baginya.

2. Tidak dilakukan penuntutan melainkan atas pengaduan suami/istri yang tercemar, dan bilamana bagi mereka berlaku pasal 27 BW, dalam tenggang waktu tiga bulan diikuti dengan permintaan bercerai atau pisah-meja dan ranjang karena alasan itu juga.

3. Terhadap pengaduan ini tidak berlaku pasal 72, 73, dan 75 .

4. Pengaduan dapat ditarik kembali selama pemeriksaan dalam sidang pengadilan belum dimulai.

2 Mukhobar dkk, Glosarium Perkawinan, Istilah-Istilah dalam Perkawinan, (Tangerang Selatan Cet. I; Dar ElIkhsan: Bambu Apus Pamulang, 2013), hlm. 101. 
5. Jika bagi suami-istri berlaku pasal $27 \mathrm{BW}$, pengaduan tidak diindahkan selama perkawinan belum diputuskan karena perceraian atau sebelum putusan yang menyatakan pisah meja dan tempat tidur menjadi tetap.

Berdasarkan asas keberlakuan undang-undang yakni asas lex posterior derogat lege priori (undang-undang yang berlaku kemudian mengesampingkan undang-undang terdahulu sejauh mengatur objek yang sama), maka pemberlakuan Pasal 284 KUHP harus mengikuti ketentuan yang dimuat dalam UUP. Dalam hal ini adalah ketentuan Pasal 2 ayat (1) dan ayat (2) UUP sebagaimana disebut di atas bahwa nikah siri tanpa adanya izin dari istri yang sah dapat memberi ruang delik perzinaan sepanjang pelaku nikah siri tidak dapat membuktikan bahwa benar telah ada perkawinan yang sah sebagaimana ketentuan Pasal 2 ayat (1) UUP di atas, dan hanya bisa dituntut berdasarkan adanya pengaduan dari istri/suami yang tercemar (delik aduan). Delik aduan menurut Abu Ayyub Saleh, adalah delik yang dapat dilakukan penuntutan delik sebagai syarat penyidikan dan penuntutan apabila ada pengaduan dari pihak yang dirugikan/korban. Merupakan sebuah perdebatan (perbedaan pendapat) dalam segi perspektif hukum, apabila membenturkan nikah siri ke dalam ranah hukum agama dan hukum pidana positif di Indonesia. ${ }^{3}$

Pengadilan dapat memberi izin kepada suami untuk beristri lebih dari satu orang apabila dikehendaki oleh pihak-pihak yang bersangkutan. Izin dari peradilan agama dapat diberikan kepada seorang suami yang akan berpoligami apabila berlaku ketentuan:

a) Istri tidak dapat menjalankan kewajibannya sebagai seorang istri

b) Istri mendapat cacat badan atau penyakit yang tidak dapat disembuhkan

c) Istri tidak dapat melahirkan keturunan

Namun untuk dapat berpoligami ada 5 syarat-syarat dalam Islam yang harus dipenuhi adalah:

1. Jumlah istri maksimal 4 orang

Banyak pria yang menjadikan dalil poligami agar ia bisa menikah lagi dan lagi tanpa mengenal batasan. Bahkan tak sedikit pria-pria yang menikahi wanita hingga 5 sampai 10 kali hanya sebagai pemuas nafsu belaka. Hal ini tentu tidak benar. Berdasarkan syariat agama, poligami hanya boleh dilakukan sebanyak 4 kali, tidak lebih dari itu.

${ }^{3}$ C.S.T Kansil dan Christine S.T. Kansil, Pokok-pokok Hukum Pidana, Jakarta: Graha Pustaka, 2004, hlm 89. 
2. Mampu berlaku adil terhadap istri

Syarat poligami menurut islam yang selanjutnya yakni suami harus bisa berlaku adil terhadap istri-istrinya. Adil disini meliputi banyak hal, termasuk dalam nafkah lahir dan batin. Apabila suami membelikan istri pertama rumah, maka istri kedua juga harus dibelikan rumah. Dalam memberikan rasa kasih sayang (termasuk kebutuhan seksual) kadarnya harus sama.

3. Tidak melupakan ibadah kepada Allah SWT

Terkadang ketika seorang pria memiliki banyak istri dan keturunan, mereka lantas melupakan ibadahnya. Mereka terlalu sibuk bekerja menafkahi keluarga. Terlalu sibuk bersenang-senang dengan istri dan anak-anaknya, kemudian saling berbangga diri hingga melalaikan Allah Ta'ala. Seolah-seolah mereka hidup di dunia selamanya. Berhati-hatilah. Jangan sampai kenikmatan dunia melupakanmu dari akhirat. Niatkanlah menikah untuk ibadah kepada Allah, bukan sebagai ajang pelampiasan nafsu semata. Dengan demikian, insyaAllah kehidupan rumah tangga insyaAllah bisa menjadi lebih berkah dan terhindar dari keburukan dunia.

4. Dilarang berpoligami dengan dua wanita yang bersaudara

Dalam melakukan poligami, sebaiknya pilihlah istri-istri dari keturunan yang berbeda-beda. Pernikahan yang dilakukan terhadap dua wanita yang masih memiliki hubungan darah erat (misalnya saudara atau bibi) tidak diperbolehkan dalam islam.

5. Mampu menjaga kehormatan istri-istrinya

Seorang suami memiliki kewajiban membimbing dan mendidik istrinya untuk hidup di jalan yang lurus sesuai syariat agama. Sebab suami adalah pemimpin keluarga. Apabila ia membiarkan istrinya bersikap bebas dan bermaksiat, maka suami pun juga ikut berdosa. Tak peduli seberapa banyak istrinya, entah itu satu, dua, tiga atau empat, semuanya harus bisa dididik secara benar. ${ }^{4}$

Berlakunya peraturan poligami yang mengharuskan adanya persetujuan dari pihak istri yang mendapatkan pengesahan dari pengadilan agama, ternyata menyebabkan seseorang yang mempunyai niat untuk poligami berusaha mengambil jalan pintas dengan melangsungkan pernikahan secara siri. Melalui pernikahan ini, mereka yakin akan

${ }_{4}^{4}$ Abdurrahman, Kompilasi Hukum Islam di Indonesia Dasar-dasar perkawinan, Jakarta: Akademika Presindo, 2000, hlm 113. 
mendapatkan kemudahan, disamping dapat menghindari dari beban hukum yang mungkin diterimanya.

Mengenai urgensi pencatatan Perkawinan nikah siri banyak sekali dilakukan namun disalah gunakan, kebiasaan membiarkan berkembangnya perbuatan nikah siri satu hal yang lain. Ternyata hal ini tidak bagus bagi pencatatan kependudukan. Seharusya kita tidak abai dan anggap sebelah mata nikah siri. Intinya, meski nikah siri jangan lewatkan pencatatannya. Teknis pengadministrasian data kependudukan saat ini jauh lebih berkembang dari masa lalu. Melalui tulisan atau gambar sebagai bukti atas diadakannya peristiwa tersebut. Salah satu cara membuktikan adanya perkawinan yaitu melalui pencatatan. Pencatatan Perkawinan adalah kegiatan menulis yang dilakukan oleh seseorang mengenai suatu peristiwa yang terjadi. Pencatatan perkawinan sangat penting, sebab buku nikah yang diperoleh merupakan bukti otentik tentang keabsahan pernikahan itu, baik secara agama maupun negara. Dengan buku nikah, mereka (suami-isteri) dapat membuktikan pula keturunan sah yang dihasilkan dari perkawinan tersebut dan memperoleh hak-haknya sebagai ahli waris. ${ }^{5}$ Fakta empiris, perkawinan di Indonesia ada yang tercatat dan ada yang tidak tercatat.

Berdasarkan latar belakang masalah di atas maka penulis dapat merumuskan permasalahan sebagai berikut: (1) Bagaimana pandangan masyarakat atas nikah siri menjadi sah menurut agama serta berdasarkan pasal 284 KUHP? (2) Bagaimana perlindungan hukum bagi istri yang ditelantarkan oleh suaminya yang sudah Nikah Siri?

\section{METODE PENELITIAN}

Pada penelitian ini menggunakan pendekatan yuridis normatif. Pada metode pendekatan ini mengkaji permasalahan hukum berdasarkan aturan normatif apakah sesuai dengan kehidupan masyarakat. Untuk mendapatkan data dan informasi yang dimaksud oleh jurnal ini maka penulis menggunakan sifat penelitian analisis kualitatif. Penelitian ini menguraikan atau mendeskripsikan data yang diperoleh secara normatif lalu diuraikan untuk mendeskripsikan data yang dikumpulkan secara sistematis. Bahan hukum primer yakni bahan-bahan hukum yang mengikat dan terdiri dari aturan-aturan normatif yang berkaitan dengan permasalahan hukum yang ada. Teknik pengumpulan data yang dilakukan dengan cara penelitian studi kepustakaan (library research), yaitu penelitian yang

${ }^{5}$ Abdul Mannan, Aneka Masalah Hukum Perdata Islam di Indonesia. Jakarta: Kencana,2000, hlm 20. 
dilakukan dengan cara meneliti bahan pustaka atau yang disebut dengan data sekunder. Analisa data yang dilakukan dalam penelitian ini yaitu menggunakan data kualitatif. Metode analisa data kualitatif ini digunakan agar penulis dapat lebih tertuju dalam memahami dan menelaah bahan-bahan hukum serta perundang-undangan yang berhubungan dengan topik yang menjadi judul dalam penulisan ini.

\section{PEMBAHASAN}

\section{A. Pandangan Masyarakat atas Nikah Siri Menjadi Sah menurut Agama serta Berdasarkan Pasal 284 KUHP}

\section{Pandangan Masyarakat atas Nikah Siri menjadi Sah menurut Agama}

Memang, dalam hukum agama Islam nikah siri bukanlah satu halyang dilarang, dengan syarat pernikahan tersebut telah memenuhi rukundan syarat sahnya nikah. Namun, nikah siri tetap saja tidak akan dianggap sah di mata hukum kenegaraan (Indonesia), hal ini berdasarkan Undang-undang Perkawinan pasal 2 ayat 2 yang berbunyi: “Tiap-tiap perkawinan dicatat menurut peraturan perundang-undangan yang berlaku”. Berdasarkan Undang-undang tersebut, maka pernikahan yang tidak dicatatkan ke Kantor Urusan Agama (KUA) atau Kantor Catatan Sipil setempat tidak akan diakui oleh negara.

Pemberlakuan Undang-undang Perkawinan pasal 2 ayat 2 di atas memang dilakukan oleh negara (Indonesia) bukan tanpa adanya alasan yang kuat. Selain sebagai data pemerintah, juga bertujuan untuk memperkecil resiko banyaknya kerugian atau kesewenang-wenangan yang akan dialami oleh seorang wanita (isteri) dan anak-anak dari hasil nikah siri, baik kerugian dalam aspek sosial maupun hukum.

Dalam hasil penelitian pada masyarakat Desa Karawang Kulon Kabupaten Karawang, maka secara umum ada dua pendapat tentang nikah siri ada yang berpendapat bahwa nikah siri itu sah dan ada yang berpendapat bahwa nikah siri itu tidak sah.

a. Masyarakat yang mengatakan nikah siri sah

Pendapat Enday selaku masyarakat desa karawang kulon yang mengatakan bahwa:

"Nikah siri adalah sah hanya saja tidak mempunyai kekuatan hukum, argumentasi ini didasarkan pada bahwa ketika suatu pernikahan telah memenuhi syarat dan rukun maka pernikahan tersebut adalah sah, mengenai kaitanya dengan pencatatan perkawinan hanyalah sebagai sebuah bukti hitam di atas putih dengan demikian pernikahan dalam kacamata islam dipandang sah apabila terpenuhinya syarat rukun tersebut, meskipun tidak dicatatkan di KUA. Dari apsek pernikahannya, nikah sirri tetap sah menurut syariat, namun tentunya bagi pelaku nikah sirri mempunyai alasan tertentu. bahwa nikah siri hanya bentuk marginalisasi terhdap hak-hak perempuan 
dan anak karena mereka tidak punya kekuatan hukum." ${ }^{\text {"6 }}$

Selanjutnya beliau juga mengatakan tanggapannya tentang nikah siri yang dilakukan masyarakat desa karawang kulon:

"Menurut saya ada tiga faktor yang mengapa orang melakukan nikah siri yang pertama mungkin untuk mengurangi praktek perzinaan dan pergaulan bebas jadi dia melakukan pernikahan siri dari pada dosa kan nikah siri juga sah kalau secara agama, yang kedua untuk mengurangi biaya ekonomi secara kan biaya pernikahan jaman sekarang sangat mahal dan yang ketiga terjaganya hukum suatu agama, jadi pernikahan siri dilakukan hanya untuk terjaganya suatu hukum agama karena jika sudah terpenuhinya rukun pernikahan maka sah sah saja mau itu nikah siri atau nikah yang resmi yang di catat di KUA."7

Hukum nikah Siri secara agama Islam adalah sah atau legal dan dihalalkan atau diperbolehkan jika syarat dan rukun nikahnya terpenuhi pada saat nikah siri digelar. Rukun nikah yaitu; (1) Adanya kedua mempelai, (2) Adanya wali, (3) Adanya saksi nikah, (4) Adanya mahar atau maskawin, (5) Adanya ijab kabul atau akad. ${ }^{8}$

b. Masyarakat yang mengatakan nikah siri tidak sah

Menurut pendapat Muadi warga desa karawang kulon berpendapat berbeda dengan Enday, Muadi mengatakan:

"Pernikahan yang sebenarnya itu harus dicatatkan dan dilaksanakan oleh pejabat yang berwenag (KUA). Memang secara agama sah karena dalam rukun pernikahan sudah terpenuhi syarat-syaratnya tetapi kan negara kita ini negara hukum ada peraturan yang mengatur tentang pernikahan. Lagi pula nikah siri itu merugikan bagi perempuan dan anaknya kelak karena tidak mempunyai kekutan hukum seperti untuk mengurus surat-surat seperti KK, Akte si anak dll. Pernikahan siri memang tidak mempunyai kekuatan hukum jadi jika suatu saat terjadi permasalahan dalam rumah tangganya tidak dapat menuntut secara hukum yang berlaku."”

Menurut hukum Islam Nikah Siri sah apabila (ada wali, saksi, ijab qabul dan mahar). Di dalam kompilasi hukum Islam Pasal 2 Ayat 1 ini, dijelaskan bahwa sebuah perkawinan adalah sah apabila dilakukan menurut hukum masing-masing agamanya dan kepercayaannya itu. Ini berarti bahwa jika suatu perkawinan telah memenuhi syarat dan rukun nikah atau ijab kabul telah dilaksanakan (bagi umat Islam), maka perkawinan tersebut adalah sah terutama di mata agama Islam dan kepercayaan masyarakat. Tetapi sahnya perkawinan ini di mata agama Islam dan kepercayaan masyarakat perlu disahkan lagi oleh negara, yang dalam hal ini ketentuannya terdapat pada Pasal 2 Ayat 2 UU Perkawinan, tentang pencatatan perkawinan. Bagi mereka yang melakukan perkawinan

\footnotetext{
${ }^{6}$ Enday, Hasil Wawancara Pribadi pada tanggal 17 April 2018 pukul 13:45.

7 Ibid.

8 Ahmad Rofiq, Hukum Islam di Indonesia, Jakarta, RajaGrafindo Persada, 2000, hlm. 131.

9 Muadi, Wawancara Pribadi pada tanggal 17 April 2018 pada pukul 14:30.
} 
menurut agama Islam pencatatan dilakukan di KUA untuk memperoleh Akta Nikah sebagai bukti dari adanya perkawinan tersebut. (pasal 7 ayat 1 Kompilasi Hukum Islam (KHI) "perkawinan hanya dapat dibuktikan dengan Akta Nikah yang dibuat oleh Pegawai Pencatat Nikah"). ${ }^{10}$

Menurut ajaran Islam, nikah itu tidak boleh secara sembunyi-sembunyi, tetapi harus dipublikasikan agar warga, tetangga, handai taulan mengetahuinya. Nabi memberi pesan agar nikah itu dipublikasikan (diwalimahkan), dan disebarluaskan kepada keluarga dan tetangga. Bahkan Beliau menganjurkan agar melaksanakan walimah walaupun hanya memotong seekor kambing. Yang bisa peroleh dari publikasi nikah itu adalah agar terhindar dari fitnah dan buruk sangka orang lain kepada yang bersangkutan, sekaligus menutup adanya kemungkinan yang bersangkutan (khususnya istri) diminati oleh orang lain. Walaupun demikian, mungkin dalam satu kasus nikah Siri itu dianggap perlu karena pertimbangan-pertimbangan kemaslahatan bersama, baik dari pihak suami atau pihak istri. Artinya nikah Siri itu dilakukan dalam rangka penyelamatan yang bersangkutan dari kemungkinan sesuatu mudarat apabila nikah Siri itu cepat-cepat dipublikasikan.

\section{Nikah siri menjadi sah berdasarkan pasal 284 KUHP}

Di Indonesia mengenai perkawinan diatur dalam UU No. 1 Tahun 1974 Tentang Perkawinan (UUP). Pasal 2 ayat (1) UUP menyebutkan bahwa: "Perkawinan adalah sah, apabila dilakukan menurut bukum masing-masing agamanya dan kepercayaannya itu”.

Jadi perkawinan adalah sah bila telah dilakukan menurut hukum agama dan kepercayaan pasangan yang kawin. Pasal ini menempatkan hukum agama dan kepercayaan adalah hal yang paling utama dalam perkawinan, dan secara implisit tidak ada larangan oleh Negara terhadap nikah siri. Namun, lebih lanjut Pasal 2 ayat (2) UUP menyebutkan adanya kewajiban untuk tiap-tiap perkawinan di catat menurut peraturan perundang-undangan yang berlaku. Perkawinan yang dicatatkan guna mendapatkan akta perkawinan. Akta perkawinan adalah bukti telah terjadinya/berlangsungnya perkawinan, bukan yang menentukan sah tidaknya perkawinan. Tidak ada bukti inilah yang menyebabkan anak maupun istri dari perkawinan siri tidak memiliki status hukum (legalitas) di hadapan Negara. Namun, lebih lanjut Pasal 2 ayat (2) UUP menyebutkan adanya kewajiban untuk tiap-tiap perkawinan dicatat menurut peraturan perundang-undangan yang berlaku. Perkawinan yang

${ }^{10}$ Mohd. Idris Ramulyo, Hukum Perkawinan, Hukum Kewarisan, Hukum Acara Peradilan Agama dan Zakat (Cet. IV; Jakarta: Sinar Grafika, 2006), hlm. 87. 
dicatatkan guna mendapatkan akta perkawinan. Akta perkawinan adalah bukti telah terjadinya/berlangsungnya perkawinan, bukan yang menentukan sah tidaknya perkawinan. Tidak ada bukti inilah yang menyebabkan anak maupun istri dari perkawinan siri tidak memiliki status hukum (legalitas) di hadapan Negara.

Dalam pasal 284 KUHP berbunyi:

1) Diancam dengan pidana penjara paling lama sembilan bulan:

a. Seorang pria yang telah kawin melakukan mukah (Overspel) padahal diketahui pasal 27 BW berlaku baginya;

b. Seorang wanita yang telah kawin melakukan mukah.

c. Seorang pria yang turut serta melakukan perbuatan itu, padahal diketahuinya, bahwa yang turut berssalah telah kawin.

d. Seorang wanita yang telah kawin yang turut serta melakukan perbuatan itu, padahal diketahui olehnya bahwa yang turut bersalah telah kawin dan pasal 27 BW berlaku baginya.

2) Tidak dilakukan penuntutan melainkan atas pengaduan suami/istri yang tercemar, dan bila mana bagi mereka berlaku pasal 27 BW, dalam tanggung waktu tiga bulam diikuti dengan permintaan bercerai atau pindah meja atau ranjang karena alasan itu juga.

3) Terhadap pengaduan ini tidak berlaku pasal 72, pasal 73, pasal 75 KUHP.

4) Pengaduan dapat ditarik kembali selama pemeriksaan dalam sidang pengadilan belum dimulai.

5) Jika bagi suami istri berlaku pasal $27 \mathrm{BW}$, pengaduan dapat diindahkan selama perkawinan belum diputuskan karena perceraian sebelum putusan yang menyatakan pisah meja atau ranjang menjadi tetap.

Pasal ini mengatur tentang perzinaan, atau yang biasa disebut mukah (overspel). Perzinaan adalah persetubuhan yang dilakukan oleh laki-laki dengan perempuan dimana salah satu atau dua-duanya sudah menikah dengan orang lain. Agar bisa dijerat dengan pasal ini, perzinaan tersebut dilakukan dengan suka sama suka. Nikah siri tanpa adanya izin dari istri yang sah dapat memberi ruang delik perzinaan sepanjang pelaku nikah siri tidak dapat membuktikan bahwa benar telah ada perkawinan yang sah sebagaimana ketentuan Pasal 2 ayat (1) UUP di atas, dan hanya bisa dituntut berdasarkan adanya 
pengaduan dari istri/suami yang tercemar (delik aduan).

Delik aduan menurut Abu Ayyub Saleh, adalah delik yang dapat dilakukan penuntutan delik sebagai syarat penyidikan dan penuntutan apabila Bahwa nikah siri tanpa adanya izin dari istri yang sah dapat memberi ruang delik perzinaan sepanjang pelaku nikah siri tidak dapat membuktikan bahwa benar telah ada perkawinan yang sah sebagaimana ketentuan Pasal 2 ayat (1) UUP di atas, dan hanya bisa dituntut berdasarkan adanya pengaduan dari istri/suami yang tercemar (delik aduan). Delik aduan menurut Abu Ayyub Saleh, adalah delik yang dapat dilakukan penuntutan delik sebagai syarat penyidikan dan penuntutan apabila ada pengaduan dari pihak yang dirugikan/korban. Merupakan sebuah perdebatan (perbedaan pendapat) dalam segi perspektif hukum, apabila membenturkan nikah siri ke dalam ranah hukum agama dan hukum pidana positif di Indonesia. ${ }^{11}$

Pengadilan dapat member izin kepada suami untuk beristri lebih dari satu orang apabila dikehendaki oleh pihak-pihak yang bersangkutan. Izin dari peradilan agama dapat diberikan kepada seorang suami yang akan berpoligami apabila berlaku ketentuan: (a) Istri tidak dapat menjalankan kewajibannya sebagai seorang istri, (b) Istri mendapat cacat badan atau penyakit yang tidak dapat disembuhkan, dan (c) Istri tidak dapat melahirkan keturunan

Namun untuk dapat berpoligami ada 5 syarat-syarat dalam islam yang harus dipenuhi adalah:

1. Jumlah istri maksimal 4 orang

Banyak pria yang menjadikan dalil poligami agar ia bisa menikah lagi dan lagi tanpa mengenal batasan. Bahkan tak sedikit pria-pria yang menikahi wanita hingga 5 sampai 10 kali hanya sebagai pemuas nafsu belaka. Hal ini tentu tidak benar. Berdasarkan syariat agama, poligami hanya boleh dilakukan sebanyak 4 kali, tidak lebih dari itu.

2. Mampu berlaku adil terhadap istri

Syarat poligami menurut islam yang selanjutnya yakni suami harus bisa berlaku adil terhadap istri-istrinya. Adil disini meliputi banyak hal, termasuk dalam nafkah lahir dan batin. Apabila suami membelikan istri pertama rumah, maka istri kedua juga harus dibelikan rumah. Dalam memberikan rasa kasih sayang

11 C.S.T Kansil dan Christine S.T. Kansil , Pokok-pokok Hukum Pidana, Jakarta, RajaGrafindo Persada, 2000, hlm. 69. 
(termasuk kebutuhan seksual) kadarnya harus sama.

3. Tidak melupakan ibadah kepada Allah SWTT

Terkadang ketika seorang pria memiliki banyak istri dan keturunan, mereka lantas melupakan ibadahnya. Mereka terlalu sibuk bekerja menafkahi keluarga. Terlalu sibuk bersenang-senang dengan istri dan anak-anaknya, kemudian saling berbangga diri hingga melalaikan Allah Ta'ala. Seolah-seolah mereka hidup di dunia selamanya. Berhati-hatilah. Jangan sampai kenikmatan dunia melupakanmu dari akhirat. Niatkanlah menikah untuk ibadah kepada Allah, bukan sebagai ajang pelampiasan nafsu semata. Dengan demikian, insyaAllah kehidupan rumah tangga insyaAllah bisa menjadi lebih berkah dan terhindar dari keburukan dunia.

4. Dilarang berpoligami dengan dua wanita yang bersaudara

Dalam melakukan poligami, sebaiknya pilihlah istri-istri dari keturunan yang berbeda-beda. Pernikahan yang dilakukan terhadap dua wanita yang masih memiliki hubungan darah erat (misalnya saudara atau bibi) tidak diperbolehkan dalam islam.

5. Mampu menjaga kehormatan istri-istrinya

Seorang suami memiliki kewajiban membimbing dan mendidik istrinya untuk hidup di jalan yang lurus sesuai syariat agama. Sebab suami adalah pemimpin keluarga. Apabila ia membiarkan istrinya bersikap bebas dan bermaksiat, maka suami pun juga ikut berdosa. Tak peduli seberapa banyak istrinya, entah itu satu, dua, tiga atau empat, semuanya harus bisa dididik secara benar. ${ }^{12}$

Berlakunya peraturan poligami yang mengharuskan adanya persetujuan dari pihak istri yang mendapatkan pengesahan dari pengadilan agama, ternyata menyebabkan seseorang yang mempunyai niat untuk poligami berusaha mengambil jalan pintas dengan melangsungkan pernikahan secara siri. Melalui pernikahan ini, mereka yakin akan mendapatkan kemudahan, disamping dapat menghindari dari beban hukum yang mungkin diterimanya.

Fenomena ini menguat kepermukaan karena ada beberapa pejabat publik terkena kasus-kasus tertentu diantaranya perzinaan, kekerasan dalam rumah tangga, penelantaran

12 Abdurrahman, Kompilasi Hukum Islam di Indonesia Dasar-dasar perkawinan, Jakarta, Akademika Presindo, 2000, hlm 25. 
istri maupun anak, dan ternyata kasus-kasus yang dihadapi tersebut ada kaitannya dengan nikah siri. Pernikahan siri satu sisi dilakukan untuk menyelesaikan suatu permasalahan misalnya menghindari terjadinya perzinaan, namun di sisi lain dapat muncul permasalahan yang tidak kecil terutama bagi pihak perempuan dan anak. Secara hukum, mereka tidak memiliki status yang jelas karena dari status perkawinan tidak jelas pula. Bukti legalisasi adanya perikatan keluarga tidak ada, sehingga apabila sampai terjadi penelantaran terhadap keduanya maka tidak ada dasar yang dapat digunakan untuk menuntut hak-haknya. Status nasib anak menjadi kabur karena anak yang sah menurut undang-undang adalah anakanak yang dilahirkan dalam atau sebagai akibat dari perkawinan yang sah. Selanjutnya anak yang dilahirkan di luar perkawinan yang sah hanya mempunyai hubungan perdata dengan ibu dan keluarga ibunya. ${ }^{13}$

Keadaan akan semakin parah jika pihak perempuan hanya menjadi ibu rumah tangga saja artinya tidak memiliki matapencaharian yang digunakan untuk memenuhi kebutuhankebutuhannaya. Sedangkan masalah sosial lain yang dapat terjadi adalah jika pihak perempuan hamil maka masyarakat yang tidak mengetahui status pernikahannya bisa menganggap telah melakukan perzinahan, dan anak hasil pernikahan siri akan dianggap sebagai anak yang lahir di luar nikah. Selain itu, akte kelahiran anak tersebut selamanya hanya mencantumkan nama ibu, sedangkan nama bapak tidak tercantum. Dan akte kelahiran tersebut akan selalu digunakan oleh anak ketika harus berurusan dengan lembaga formal. Misalnya ketika mendaftar sekolah di setiap tingkat pendidikan. Ketika anak mampu memahami kondisi akte yang demikian maka dapat menimbulkan dampak psikologis yang tidak kecil bagi anak.

Atas dasar ini, maka kawin siri dipandang sebagai model dalam menolak suatu pergaulan bebas. Artinya dengan melakukan pernikahan siri hubungan mereka sebagai suami isteri yang biasanya berlangsung sebelum melakukan pernikahan dan boleh jadi melanggar hukum islam, bisa berubah menjadi halal. Tanpa memenuhi persyaratan administrasi yang diwajibkan undang-undang perkawinan siri tetap dilangsungkan dengan tujuan menghinar perbuatan yang melanggar norma agama. Dengan adanya kata perlu dihadiri penghulu, berarti secara adat pencatatan perkawinan itu hanya persyaratan administratif, tidak terkait dengan peristiwa hukum akad perkawinan. Dengan demikian, bentuk-bentuk perkawinan siri memang masih bersifat rahasia tetapi tidak dalam artian bermaksud melanggar hukum positf, semata-mata karena alasan ekonomi keluarga serta

13 Mohammad Hasan, Problematiak Nikah Siri dalam Negara Hukum Jurnal Hukum Islam, Pekalongan 2004 Vol 2 No.1, hlm 97. 
untuk menghindari pelanggaran asusila.

\section{B. Perlindungan Hukum Bagi Istri Yang Ditelantarkan Oleh Suaminya Yang Sudah Nikah Siri}

Muchsin mendefinisikan penelantaran rumah tangga adalah "setiap bentuk pelalaian kewajiban dan tanggung jawab seseorang dalam rumah tangga yang menurut hukum seseorang itu telah ditetapkan sebagai pemegang tanggung jawab terhadap kehidupan orang yang berada dalam lingkungan keluarganya". ${ }^{14}$

Perkawinan merupakan suatu perjanjian antara seorang laki-laki dengan seorang perempuan, di mana dalam perjanjian tersebut mengandung 3 karakter khusus, yaitu: ${ }^{15}$ Perkawinan tidak dilaksanakan tanpa unsur suka rela dari kedua belah pihak, Kedua belah pihak yang mengikat persetujuan perkawinan itu selagi mempunyai hak untuk menentukan perjanjian tersebut berdasarkan ketentuan yang sudah ada ketentuan hukumnya. Persetujuan perkawinan mengatur batas hukum dan kewajiban masing-masing pihak. Perkawinan yang telah melalui pencatatan dapat melindungi hak asasi bagi kaum wanita, sehingga kaum wanita tidak dilecehkan. Sebab menurut hukum positif Indonesia, perkawinan yang tidak dicatat tidak diakui sama sekali. Jadi, di dalam Struktur Kantor Urusan Agama ada petugas pencatat nikah yang biasa disebut penghulu. Penghuu yang bertanggung jawab untuk mencatat bukan menikahkan. Tapi, penghulu juga bisa bertindak menjadi naibul wali ketika wali menyerahkan untuk kewaliannya itu. Namun, hal tersebut harus ada serah terima dari wali yang sesungguhnya, tidak bisa seorang penghulu menganggat dirinya sendiri menjadi wali. Apalagi pihak lain yang mencoba untuk memposisikan dirinya sebagai penghulu dan tidak ada surat keputusan sebagai penghulu. Perkawinan yang tidak dicatat bukan merupakan perkawinan yang sah di hadapan hukum dan negara, sehingga perkawinan tersebut hanya sah menurut agama dikarenakan terpenuhinya rukun nikah.

Berdasarkan ketentuan-ketentuan hukum yang mengatur tentang pencatatan perkawinan dapat dipahami bahwa pencatatan tersebut adalah syarat administrasi. Artinya: perkawinan tetap sah, karena standar sah dan tidaknya perkawinan ditentukan oleh norma-norma agama dari pihak-pihak yang melangsungkan perkawinan. Pencatatan perkawinan diatur karena tanpa pencatatan suatu perkawinan tidak mempunyai kekuatan

14 Muchsin, Varia Peradilan no. 303, IKAHI, Jakarta, 2011, hlm. 18.

15 Irniyusnita Abas, Nikah Siri dalam Perspektif Undang-undang Perkaninan Nasional, Skripsi, Fakulatas Hukum Universitas Brawijaya, Malang, 2011, hlm. 11. 
hukum, ${ }^{16}$ sehingga akibat yang ditimbulkan adalah apabila salah satu pihak melalaikan kewajibannya, maka pihak lain tidak dapat melakukan upaya hukum. Hal ini dikarenakan tidak memiliki bukti-bukti yang sah dan otentik dari perkawinan yang dilangsungkan oleh pasangan tersebut. Konsekuensi dari perkawinan yang sah akan menimbulkan akibat hukum, seperti hak dan kewajiban suami isteri, harta perkawinan, hubungan timbal balik antara kedua orang tua dengan anak (nasab), kewajiban pemeliharaan anak (hadhanah), dan kewarisan.

Mempertimbangkan analisis di atas, maka menurut penulis perkawinan yang tidak dicatat tetap dianggap sah karena telah memenuhi rukun dan syarat perkawinan. Sedangkan mengenai pencatatan perkawinan hanya merupakan salah satu syarat administrasi saja. Dalam hal ini, menurut pendapat Bagir Manan yang menyatakan bahwa fungsi dan kedudukan pencatatan perkawinan adalah untuk menjamin ketertiban hukum yang berfungsi sebagai instrumen kepastian hukum, kemudahan hukum dan juga sebagai salah satu alat bukti perkawinan. ${ }^{17}$ Akan tetapi, akibat hukum dari perkawinan yang tidak dicatat tersebut tidak memiliki kekuatan hukum yang tetap dan dianggap tidak sah di hadapan hukum nasional. Sehingga perkawinan tersebut memiliki dampak yang sangat merugikan bagi istri atau perempuan pada umumnya baik secara hukum maupun sosial serta bagi anak yang dilahirkan dari perkawinan tersebut.

Berkaitan dengan sah tidaknya suatu perkawinan, maka status anak dapat ditentukan. Anak sah dilahirkan karena perkawinan yang sah dan apabila anak lahir bukan karena perkawinan yang sah menurut Pasal 2 Undang-Undang Nomor 1 Tahun 1974 berarti bukan anak sah. Anak yang berstatus sebagai anak yang tidak sah karena perkawinan yang hanya dilakukan menurut agama dan kepercayaannya merupakan kekeliruan yang besar yang tidak mencerminkan perlindungan hukum/ Hak Asasi Manusia (yang selanjutnya disebut HAM) yang sama sehingga menimbulkan diskriminasi. Anak terpaksa berstatus anak tidak sah, padahal perkawinan sudah dilakukan sesuai dengan agama dan kepercayaan yang dianut.

Akibat hukum dari perkawinan tersebut, meski secara agama atau kepercayaan dianggap sah, namun perkawinan yang dilakukan di luar pengetahuan dan pengawasan pegawai pencatat nikah tidak memiliki kekuatan hukum yang tetap dan dianggap tidak sah

16 Ahmad Rofiq, Hukum Islam di Indonesia, Jakarta, RajaGrafindo Persada, 2000, hlm. 110.

17 Bagir Manan, Keabsahan dan Syarat-syarat Perkawinan Antar Orang Islam Menurut UU Nomor 1 Tabun 1974, dalam Buku Neng Djubaedah, Pencatatan Perkawinan dan Perkawinan tidak dicatat, Jakarta, Sinar Grafika, 2012, hlm. 157. 
di mata hukum negara, sehingga perkawinan tersebut berdampak sangat merugikan bagi istri dan perempuan umumnya, baik secara hukum maupun sosial, serta bagi anak yang dilahirkan. Berkaitan dengan hak asasi manusia, perkawinan yang tidak dicatat telah melanggar hak asasi baik istri maupun anak dari perkawinan tersebut. Di mana tujuan perkawinan yang sebenarnya adalah untuk kebahagiaan bukan malah penderitaan yang ditanggung oleh istri dan anak.

Dengan demikian menurut pendapat penulis maka belum ada bentuk perlindungan hukum bagi istri dan anak dari perkawinan yang tidak dicatat. Namun, anak yang lahir di dalam perkawinan tersebut dapat dikatakan anak yang disahkan karena hanya ada pengakuan dari ayah anak tersebut dan harus disertai putusan pengadilan. Dengan demikian, akibat hukum tidak dicatatnya perkawinan adalah perkawinan dianggap tetap sah, sehingga meski perkawinan dilakukan menurut agama dan kepercayaan, namun di mata negara perkawinan tersebut dianggap tidak mempunyai kekuatan hukum jika belum dicatat oleh Kantor Urusan Agama. Maka dari itu, untuk pembuktian asal usul anak yang dilahirkan dalam perkawinan tersebut dilakukan di Pengadilan Agama dengan mengajukan bukti-bukti yang dapat memperkuat hak dan kewajiban para pihaknya. Hal tersebut biasanya dilakukan bersamaan dengan diajukannya permohonan Itsbat nikah oleh orang tua anak tersebut karena keabsahan seorang anak dapat dibuktikan melalui akta kelahiran.

\section{Bentuk-Bentuk Penelantaran Terhadap Istri}

Menurut pasal tersebut, maka penelantaran terhadap isteri dibagi menjadi dua bentuk:

1. Tidak memberikan nafkah

Salah satu kewajiban suami adalah memenuhi segala kebutuhan istri sesuai dengan kemampuannya, berdasarkan Pasal 34 ayat (1) UU No. 1 Tahun 1974 tentang Perkawinan: "Suami wajib melindungi isterinya dan memberikan segala sesuatu keperluan hidup berumah tangga sesuai dengan kemampuannya". Dalam Pasal 80 ayat (4) KHI dikatakan, sesuai dengan kemampuannya suami menanggung:

a) Nafkah, kiswah dan tempat kediaman bagi istri;

b) Biaya rumah tangga, biaya perawatan dan biaya pengobatan bagi istri dan anak;

c) Biaya pendidikan bagi anak

Selain penelantaran dalam arti tidak memberikan istri kebutuhan dasarnya di 
atas, penelantaran istri juga termasuk membiarkan istri yang bekerja untuk dieksploitasi sementara suami tidak memenuhi kebutuhannya, suami juga tidak memberikan gajinya pada istri karena istrinya berpenghasilan, suami menyembunyikan gajinya, mengambil harta istri, tidak memberi uang belanja yang mencukupi, atau tidak memberi uang belanja sama sekali, menuntut istri memperoleh penghasilan lebih banyak.

Jika suami dan istri masing-masing mempunyai penghasilan, maka tetap kewajiban memberi nafkah ini berada di pundak suami, kecuali istri bersedia membebaskan sebagian kewajiban suami karena adanya bantuan dari penghasilan istri. Begitupun ketika penghasilan istri lebih besar dari penghasilan suaminya, istri tetap berhak dinafkahi dan bisa membebaskan suami dari dari kewajibannya sebagian bahkan seluruhnya berdasar Pasal 80 ayat (6). Dan tidak menutup kemungkinan pula bahwa batas kemampuan suami hanya sampai demikian. Persoalan sampai dimana batas kemampuan suami, maka itu diserahkan sepenuhnya kepada adat kebiasaan masyarakat setempat, dan hakim yang berhak menentukan suami ini mampu atau tidak. Dalam hal pasangan suami istri ini membuat perjanjian perkawinan mengenai pemisahan harta bersama, maka perjanjian tersebut tidak boleh menghilangkan kewajiban suami untuk memenuhi.

\section{Membuat Ketergantungan}

Selain tidak memberikan nafkah kepada istri, penelantaran suami juga dapat dikatakan perilaku pelarangan istri bekerja dan mengontrol ruang gerak istri. Yaitu setiap tindakan suami yang membatasi istri untuk bekerja di dalam atau di luar rumah untuk menghasilkan uang dan barang serta tidak mengizinkan istri untuk meningkatkan karirnya.

Pelarangan istri untuk bekerja ini ditekankan kepada 2 hal, yaitu:

a) Melarang istri bekerja karena akan mengakibatkan ketergantunganekonomi, sehingga ketika suami tidak ada maka istri tidak bisa mandiri memenuhi kebutuhannya sendiri.

b) Melarang istri bekerja dengan tujuan mengendalikan istri sehingga membuka kemungkinan suami bertindak sewenang-wenang

Faktor ketergantungan istri dalam hal ekonomi kepada suami memaksa istri 
untuk menuruti semua keinginan suami meskipun ia merasa menderita. Bahkan sekalipun tindakan keras dilakukan kepadanya ia tetap enggan untuk melaporakn penderitaanya dengan pertimbangan demi kelangsunhgan hidup dirinya dan kelangsungan hidup bagi anak-anaknya. Hal ini dimanfaatkan oleh suami untuk bertindak sewenang-wenangnya kepada isterinya. ${ }^{18}$

Di dalam Undang-Undang perkawinan menyatakan secara tegas bahwa kedudukan suami istri seimbang, dalam melakukan perbuatan hukum. Bentuk perlindungan hukum bagi istri yang di yang ditelantarkan oleh suaminya yang sudah Nikah Siri yaitu seorang suami berkewajiban untuk memenuhi hak-hak istri sebagaimana yang tercantum dalam UU Nomor 1 Tahun 1974 Tentang Perkawinan, diantaranya:

1) Pasal 30 UU Nomor 1 Tahun 1974 Tentang Perkawinan ; (1) Hak dan kedudukan isteri adalah seimbang dengan hak dan kedudukan suami dalam kehidupan rumah tangga dan pergaulan hidup bersama dalam masyarakat.

2) Pasal 35 UU Nomor 1 Tahun 1974 Tentang Perkawinan; (1) Harta benda yang diperoleh selama perkawinan menjadi harta bersama. (2) Harta bawaan dari masing-masing suami dan isteri dan harta benda yang diperoleh masing-masing sebagai hadiah atau warisan, adalah dibawah penguasaan masing-masing sepanjang para pihak tidak menentukan lain.

3) Pasal 36 UU Nomor 1 Tahun 1974 Tentang Perkawinan ; (2) mengenai harta bawaan masing-masing, suami dan isteri mempunyai hak sepenuhnya untuk melakukan perbuatan hukum mengenai harta bendanya.

\section{KESIMPULAN}

Berdasarkan uraian diatas dapat disimpulkan bahwa Hukum nikah Siri secara agama Islam adalah sah atau legal dan dihalalkan atau diperbolehkan jika syarat dan rukun nikahnya terpenuhi pada saat nikah Siri digelar. Rukun nikah yaitu; (1) Adanya kedua

18 Intan Kafa Arbina, Perlindungan Hukum Terhadap Korban Tindak Pidana Kekerasan Dalam Rumah Tangga (Kdrt), Studi Di Pengadilan Negeri Slawi Dibubungkan Dengan Putusan Nomor: 116/Pid.B/2007/Pn. Slawi. hlm 46. 
mempelai, (2) Adanya wali, (3) Adanya saksi nikah, (4) Adanya mahar atau maskawin, (5) Adanya ijab kabul atau akad.

Di Indonesia mengenai perkawinan diatur dalam UU No. 1 Tahun 1974 Tentang Perkawinan (UUP). Pasal 2 ayat (1) UUP. Jadi perkawinan adalah sah bila telah dilakukan menurut hukum agama dan kepercayaan pasangan yang kawin. Pasal ini menempatkan hukum agama dan kepercayaan adalah hal yang paling utama dalam perkawinan, dan secara implisit tidak ada larangan oleh Negara terhadap nikah siri.

Perkawinan tidak dilaksanakan tanpa unsur suka rela dari kedua belah pihak, Kedua belah pihak yang mengikat persetujuan perkawinan itu selagi mempunyai hak untuk menentukan perjanjian tersebut berdasarkan ketentuan yang sudah ada ketentuan hukumnya. Persetujuan perkawinan mengatur batas hukum dan kewajiban masing-masing pihak. Perkawinan yang telah melalui pencatatan dapat melindungi hak asasi bagi kaum wanita, sehingga kaum wanita tidak dilecehkan. Sebab menurut hukum positif Indonesia, perkawinan yang tidak dicatat tidak diakui sama sekali.

\section{DAFTAR PUSTAKA}

\section{Buku}

Abdurrahman, 2000, Kompilasi Hukum Islam di Indonesia Dasar-Dasar Perkawinan, Jakarta, Akademika Presindo.

Ahmad Rofiq, 2000, Hukum Islam di Indonesia, Jakarta, RajaGrafindo Persada.

Bagir Manan, 2012, Keabsahan dan Syarat-syarat Perkawinan Antar Orang Islam Menurut UU Nomor 1 Tahun 1974, dalam Buku Neng Djubaedah, Pencatatan Perkawinan dan Perkawinan tidak dicatat, Jakarta, Sinar Grafika.

C.S.T Kansil dan Christine S.T. Kansil, 2004, Pokok-pokok Hukum Pidana, Jakarta: Graha Pustaka.

C.S.T Kansil dan Christine S.T. Kansil , 2000, Pokok-pokok Hukum Pidana, Jakarta, Raja Grafindo Persada.

Irniyusnita Abas, 2011, Nikah Siri dalam Perspektif Undang-undang Perkawinan Nasional, Skripsi, Malang: Fakulatas Hukum Universitas Brawijaya.

Mohd. Idris Ramulyo, 2006, Hukum Perkawinan, Hukum Kewarisan, Hukum Acara Peradilan Agama dan Zakat Cet. IV; Jakarta: Sinar Grafika.

Mukhobar dkk, 2013, Glosarium Perkawinan, Istilah-Istilah dalam Perkawinan, (Tangerang Selatan Cet. I; Dar ElIkhsan: Bambu Apus Pamulang.

Intan Kafa Arbina, Perlindungan Hukum Terbadap Korban Tindak Pidana Kekerasan Dalam Rumah Tangga (Kdrt), Studi Di Pengadilan Negeri Slawi Dibubungkan Dengan Putusan Nomor: 116/Pid.B/2007/Pn. Slawi. 


\section{Jurnal}

Muchsin, 2011, Varia Peradilan no. 303, Jakarta, IKAHI.

Mohammad Hasan, 2004, Problematiak Nikah Siri dalam Negara Hukum Jurnal Hukum Islam, Pekalongan, Jurnal.

\section{Peraturan Perundang-undangan}

Undang-undang RI No. 1 tahun 1974 tentang Perkawinan

Kitab Undang-undang Hukum Pidana (KUHP)

Kompilasi Hukum Islam (KHI)

\section{Hasil Wawancara}

Enday, Hasil Wawancara Pribadi pada tanggal 17 April 2018 pukul 13:45

Muadi, Wawancara Pribadi pada tanggal 17 April 2018 pada pukul 14:30

\section{Internet}

https://dalamislam.com/hukum-islam/pernikahan/nikah-siri-dalam-islam, diakses pada tanggal 28 mei 2020 